\title{
Distribution, relative abundance, biomass and production of bay anchovy Anchoa mitchilli in the Chesapeake Bay
}

\author{
Shyh-Bin Wang*, Edward D. Houde \\ University of Maryland, Chesapeake Biological Laboratory, PO Box 38, Solomons, Maryland 20688-0038, USA
}

\begin{abstract}
Seasonal distribution, relative abundance, biomass production, population consumption, and energy storage in bay anchovy Anchoa mitchilli were estimated from midwater trawl surveys in the upper and mid Chesapeake Bay from April 1990 to October 1991 Abundance and biomass both peaked in late summer and fall before declining significantly in winter, a result of southward migration to lower Bay areas that were not sampled. Production also peaked between summer and fall, a consequence of rapid growth and recruitment of larval and juvenile anchovies. Annual production of youngof -the-year (YOY) anchovy was $856.69 \mathrm{~g} 100 \mathrm{~m}^{-3}, 87.9 \%$ of which was produced in the first 3 mo of life. Production by YOY anchovy accounted for nearly all annual production ( $92.6 \%)$ in this short-lived species. Total annual production was estimated to be $233014 \mathrm{t}$ wet wt in upper to mid-Bay regions. The production/biomass $(P / \bar{B})$ ratio for YOY anchovy was 8.07 when larval and early juvenile stages were included but only 0.97 without those stages. The estimated translocation of nitrogen biomass from the upper and mid Bay to the lower Bay via anchovy migration was $1027 \mathrm{t} N$ during fall 1990, which is approximately $0.8 \%$ of the annual $\mathrm{N}$ input to Chesapeake Bay. Estimated population consumption (primarily zooplankton) by bay anchovy ranged from 5.29 to $12.81 \mathrm{~g}$ dry wt $100 \mathrm{~m}^{-3} \mathrm{~d}^{-1}$ in August and from 5.35 to $6.78 \mathrm{~g}$ dry wt $100 \mathrm{~m}^{-3} \mathrm{~d}^{-1}$ in October, suggesting that consumption by larvae and juveniles of this species could significantly impact populations of its plankton prey.
\end{abstract}

KEY WORDS: Anchovy - Biomass · Production - Consumption

\section{INTRODUCTION}

The bay anchovy Anchoa mitchilli is widely distributed in coastal bays and estuaries along the United States east coast and is the most abundant fish in the Chesapeake Bay (Hildebrand \& Schroeder 1928 Bigelow \& Schroeder 1953, Horwitz 1987, Houde \& Zastrow 1991). Bay anchovy consumes primarily zooplankton (Klebasko 1991) and is itself the prey of piscivorous fishes (Hartman 1993). Although not commercially exploited, it is a key species that may significantly influence water quality and living resources in Chesapeake Bay (Chesapeake Executive Council $1988 \mathrm{a}, \mathrm{b})$.

- Present address: Department of Marine Sciences, University of South Alabama, Dauphin Island Sea Laboratory, PO Box 369-370, Dauphin Island, Alabama 36528, USA
In freshwater ecosystems, the relationships among piscivores, planktivores and their prey have received much attention (McQueen et al. 1986, 1989, Kitchell \& Carpenter 1987, Johnson et al. 1990, DeMelo et al. 1992). In estuaries, it is possible that abundant planktivores such as bay anchovy may exercise significant top-down control over productivity and that the production level of bay anchovy may limit piscivore production. In a speculative, yet revealing, trophic network analysis, Baird \& Ulanowicz (1989) provided insight into the probable key trophic role that the bay anchovy plays in Chesapeake Bay, but biomass and production potential were not estimated. They calculated that bay anchovy might contribute from 60 to $90 \%$ to the diets of Chesapeake Bay piscivores on a seasonal basis. Hartman (1993) demonstrated that bay anchovy is preyed upon most heavily by young (age 0 to 2) piscivores in Chesapeake Bay, when the anchovy 
is a major component of their diets. A bioenergetics model, which did not include the larval stage, demonstrated the high production and consumption potential of bay anchovy in Chesapeake Bay (Luo \& Brandt 1993). Fluctuations in bay anchovy abundance and production could potentially impact production of Chesapeake Bay piscivores (e.g. striped bass Morone saxatilis, bluefish Pomatomus saltatrix and weakfish Cynoscion regalis), all of which are significant consumers of bay anchovy (Merriner 1975, Wilk 1977. Summers 1989, Hartman 1993).

We examined the distribution patterns, seasonal and annual biomass, production, food consumption and energy storage of bay anchovy at different life stages in the mesohaline Chesapeake Bay. In addition, the seasonal nitrogen biomass of bay anchovy and its potential to be translocated via migration are reported. This information, when coupled with information on body composition and energetics of bay anchovy (Wang \& Houde 1994) and compared with output from a bioenergetics model (Luo \& Brandt 1993), will provide knowledge to evaluate the trophic role of bay anchovy in Chesapeake Bay.

\section{MATERIALS AND METHODS}

Field sampling. Juvenile and adult bay anchovy were collected by midwater trawl on 5 bimonthly cruises from April 1990 through February 1991 on 2 cross-Bay transects. One transect was off the Choptank River and the second was off Point no Point (Fig. 1). Collections were also made in the upper Bay on the Still Pond and Greenberry Point transects in August, October and December 1990, and in February 1991. Three expanded cruises were carried out in April, July-August and October 1991, when extensive trawling and acoustic surveys were completed on 5 cross-Bay transects (Fig. 1). There were 4 to 7 trawl stations on each transect.

A midwater trawl with $7.6 \mathrm{~cm}$ stretch mesh at the $8 \mathrm{~m}^{2}$ mouth, $3.8 \mathrm{~cm}$ stretch mesh in the body, and a $3.2 \mathrm{~mm}$ mesh cod-end liner was used to collect bay anchovy. The trawl was towed obliquely for 15 to $25 \mathrm{~min}$ from surface to bottom at each station at a trawling speed of 1.25 to $1.50 \mathrm{~m} \mathrm{~s}^{-1}$ Temperature, salinity and dissolved oxygen profiles were obtained with a Conductivity-Temperature-Depth (CTD) sensor at each station to relate fish distribution patterns to environmental variables.

Acoustic estimates of fish abundance were made using a dual-frequency echosounder ( 38 and $120 \mathrm{kHz}$ ), which was continuously operated along each transect during the trawl surveys. Echo-squared integration and dual beam analyses of the acoustic data provided measures of acoustic target strength and fish density. Fish lengths were estimated from measured target strengths using an equation specific for clupeids (Luo $\&$ Brandt 1993). Abundances and biomasses estimated from the trawl were compared to acoustic measurements on the same transects. Fish species collected in the trawl tows were assumed to represent the species present. The trawl abundance and biomass data were calibrated from the acoustic data.

Total catches (by numbers and weight) and the length-frequency distribution of bay anchovies were recorded on deck for each tow. Total lengths of 100 to 200 bay anchovy, or all anchovies from smaller catches, were measured for each tow. Subsamples from catches were frozen for later size, age structure, sex ratio, and energy content analyses. The relative abundances $\left(N\right.$, number per $\left.100 \mathrm{~m}^{3}\right)$ were estimated from the trawl catch-per-unit-effort (CPUE, number min $^{-1}$, trawl dimensions and vessel speed by

$$
N=\frac{C}{A L} \times 100
$$

where $C$ is the number of bay anchovy in a tow, $A$ is the mouth area of the trawl $\left(8 \mathrm{~m}^{2}\right)$, and $L$ is the distance towed $(\mathrm{m})$, calculated from vessel speed $(1.25$ to $1.50 \mathrm{~m}$ $\left.\mathrm{s}^{-1}\right)$ multiplied by trawl time (15 to $25 \mathrm{~min}$ ). By substituting $W$ (catch in weight) for $C$ in each tow, the relative biomass (g $100 \mathrm{~m}^{-3}$ ) was obtained.

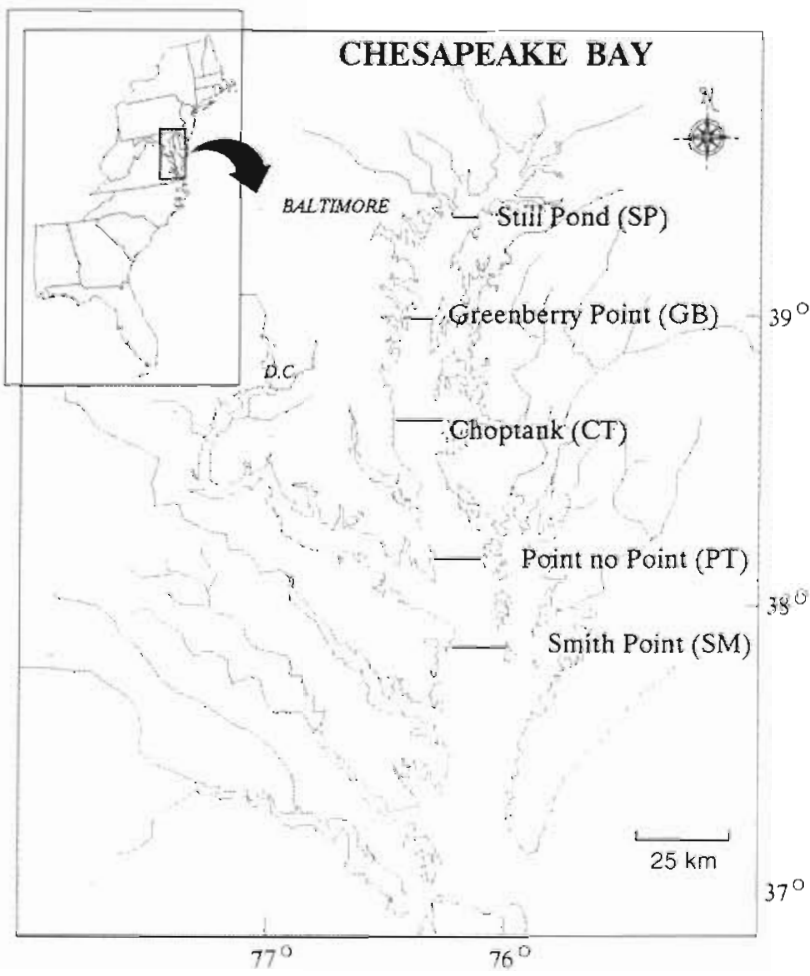

Fig. 1. Chesapeake Bay, USA, showing sampling transects. Two transects (Choptank and Point no Point) were sampled in 1990 and February 1991, and 5 transects after February 1991 
A nonparametric analysis of variance (ANOVA) was used to test for differences in length-frequency distributions and relative abundances and biomasses of bay anchovy among locations. A nonparametric, multiplecomparisons test was then applied to compare differences among specific locations. A parametric ANOVA was used to test for differences in mean lengths among locations, and Tukey's Studentized test $(\alpha=0.05)$ was applied to compare mean lengths among locations. All statistical tests were run on PC SAS (SAS 1985).

Biomass, nitrogen biomass, production and energy storage. Estimates of age, growth and mortality of bay anchovy had been obtained in 1990 and 1991 (Wang 1992). Seasonal age composition of the population had been determined from samples of otolith-aged anchovies in trawl samples from each cruise. Estimates of bay anchovy age-specific and seasonal production were obtained by the instantaneous growth rate method (Ricker 1975, Waters 1977, Newman \& Martin 1983).

The weight-specific growth rate $(G)$ for 2 mo intervals of each age group was calculated from an exponential growth model:

$$
\bar{W}_{t+1}=\bar{W}_{t} e^{G t}
$$

where $\bar{W}_{i}$ and $\bar{W}_{t+1}$ are mean wet wt at time $t$ and $t+1$, respectively, and $t$ is a 2 mo interval. This model assumes approximate exponential growth during the 2 mo interval. Alternatively, weight-specific growth coefficients were estimated by fitting weights-at-age to a von Bertalanffy growth model (Wang 1992). The 2 methods were compared with respect to production estimates.

Age-specific biomasses $(B)$ at times $t$ and $t+1$ were estimated as:

$$
B_{t+1}=\bar{W}_{t+1} N_{t+1}=\bar{W}_{t} N_{t} \mathrm{e}^{(G-Z) t}=B_{t} \mathrm{e}^{(G-Z) t}
$$

where $N_{t}$ and $N_{t+1}$ are relative abundances at times $t$ and $t+1$, respectively, and $Z$ is cumulative mortality between times $t$ and $t+1$. The mean age-specific biomasses of anchovy over 2 mo intervals were represented as:

$$
\bar{B}=\frac{B_{t}\left(e^{G-Z}-1\right)}{G-Z}
$$

(equation from Ricker 1975). The estimated production $(P)$ by each age group in each time interval was:

$$
P=G \bar{B}
$$

Annual productions were obtained by summing $P$ for age groups and time intervals. Details of an energy content analysis are reported in Wang \& Houde (1994). The protein ( $\%$ of dry wt) content was estimated from $100 \%$ - lipid $\%$ - ash $\%$; protein $(g)=$ fish dry weight $x$ protein $(\%)$; and nitrogen content $(\mathrm{g})=$ protein $(\mathrm{g}) / 6.25$
(Dowgiallo 1975). Nitrogen biomass and production, and the population's energy storage $\left(\mathrm{cal} \mathrm{m} \mathrm{m}^{-3}\right)(1 \mathrm{cal}=$ $4.184 \mathrm{~J}$ ) then were obtained by multiplying nitrogen content or energy values in each season by the corresponding biomass and production estimates

Larval and small juvenile anchovies were not vulnerable to the trawl, but must be included to obtain stagespecific estimates of annual biomass and total production for this short-lived species. We proceeded as follows:

(1) Egg production: The sex ratio of adults was 1:1 in June of the current study (Wang 1992); relative spawning biomass = mean adult biomass between June and

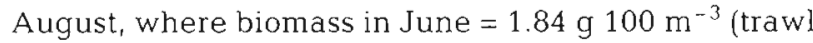
abundance) $\times 26.81$ (acoustic-calibration ratio in June) $\times 1.182 \mathrm{~g}$ (June mean body weight, $B W_{\text {Jun }}$ ) $=58.3 \mathrm{~g}$ $100 \mathrm{~m}^{-3}$; abundance of age $1+$ fish in August $\left(N_{\text {Aug-uge 1+ }}\right)$ was calculated from $N_{\text {Aug-age 1* }}=N_{\text {Ort-age }+} /$ $\mathrm{e}^{-Z}$ where $Z=$ bimonthly $Z$ [obtained from catch curve, annual $Z\left(Z_{\mathrm{A}}\right)=-1.81$ (Wang 1992), divided by 6], and $N_{\text {Oct-age }+}=N_{\text {Oct-lotal }}$ (i.e. 65.21 fish $100 \mathrm{~m}^{-3}$ ) $\times 14.9 \%$ (for age $1+$ ); biomass of age $1+$ in August $=N_{\text {Aug-age } 1+} \times$ mean $B W_{\text {Aug-agel }+;}$ spawning frequency $=50$ batches (for entire spawning season), and batch fecundity = $304.79+404.64 \times$ female wt (Zastrow et al. 1991). We assumed that dry egg weight was $15.4 \mathrm{\mu g}$ (Tucker 1989), and that water content of an egg was $80 \%$. The mean hatch date was assumed to be July 15 (Zastrow et al. 1991, Newberger \& Houde 1995). Based upon these values, the newly produced relative biomass ( $g$ $100 \mathrm{~m}^{-3}$ ) and abundance (no. $100 \mathrm{~m}^{-3}$ ) of bay anchovy eggs were calculated for the peak of the 1990 spawning season (July 15). The estimated egg biomass was credited to spawning adults (age 1+) and included in their production.

(2) Young-of-the-year and age 1+ abundances: Because bay anchovies were not fully vulnerable to the trawl in August, the mortality rates from mid-July to mid-August and mid-August to mid-October could not be estimated directly. To obtain the estimates, the cumulative mortality $(Z)$ from July 15 to October was estimated from the acoustic-calibrated trawl abundance in October and the egg abundance estimated from egg production (section 'Egg production' above) using the equation: $Z$ (for $3 \mathrm{mo}$ ) $=-\ln \left(N_{\text {Oct-YoY }}\right.$ ) $N_{\text {egg }}$ ) where $N_{\text {Oct-yoY }}=N_{\text {Oct-total }}$ (i.e. 65,21 fish $100 \mathrm{~m}^{-3}$ ) $\times 84.2 \%$ (for YOY) $\times 4.38$ (October acoustic calibration ratio). Then, we partitioned the cumulative mortalities from July-October into July-August and AugustOctober periods from the estimated $Z$ and stage duration of egg and larval bay anchovy: $Z=-1.56 \mathrm{~d}^{-1}$ for egg (Dorsey 1993) and $Z=-0.29 \mathrm{~d}^{-1}$ for larvae [egg to $14.08 \mathrm{~d}$ old (fish size $\leq 9.5 \mathrm{~mm}$ )], egg duration $=0.92 \mathrm{~d}$ (22 h) (Houde 1988) in the Chesapeake Bay. Thus, cumulative $Z$ for egg to $9.5 \mathrm{~mm}$ larvae $=(-1.56 \times 0.92 \mathrm{~d})$ 
$+[-0.29(14.08-0.92) \mathrm{d}]=-5.25$ (from egg to hatching at $2 \mathrm{~mm}$ and growing to $9.5 \mathrm{~mm}$ at $14.08 \mathrm{~d}$ ). The estimated cumulative $Z$ from mid-July to mid-August, i.e. $Z$ for $31 \mathrm{~d}$ old anchovy, $=5.25+\left[\left(Z_{\mathrm{Jul}-\mathrm{OCl}}-5.25\right) /\right.$ (number of days after $14.08 \mathrm{~d}$ old to mid-October)] $x$ $(31-14.08) d_{i}$ and cumulative $Z$ for the remainder of the juvenile stage (mid-August to mid-October) = $Z_{\text {Jul-Oct }}-Z_{\text {Jul-Aug. }}$. We assumed that the monthly mortality rate for age $1+$ anchovy was constant among seasons and was estimated from a catch-curve-derived (annual Z)/12 $=-0.151$ (Wang 1992). This approach allowed back-calculation of both YOY and age $1+$ abundances in mid-August from $N_{\text {mid-Aug }}=N_{\text {mud-Oct }} /$ $\mathrm{e}^{-z t}$, where $t=2$ mo.

Because of probable gear selectivity, the mean length of bay anchovy in August trawl catches did not accurately represent the YOY population. We estimated the mean length of YOY in August from the mean modal length on October (i.e. $51.47 \mathrm{~mm}$ ) and mean growth rate $\left(0.46 \mathrm{~mm} \mathrm{~d}^{-1}\right.$ for anchovy between 17 and $49 \mathrm{~mm}$; Zastrow et al. 1991) and number of days between the August and October sampling date $(70 \mathrm{~d})$. Back-calculated mean length of YOY in mid-August is $51.47 \mathrm{~mm}-\left(0.46 \mathrm{~mm} \mathrm{~d}^{-1} \times 70 \mathrm{~d}\right)=19.27 \mathrm{~mm}$.

(3) Weight-specific growth rates: During early life stages, from mid-July to mid-August and mid-August to mid-October, $G$ values were obtained by $\bar{W}_{12}=$ $\bar{W}_{t 1} \mathrm{e}^{(i t}$, where $\bar{W}_{t 2}$ and $\bar{W}_{t 1}$ were mean wet wt calculated from seasonal length-weight relationships (Wang 1992), based on mean length of YOY in mid-August $=19.27 \mathrm{~mm}$ and mean length in mid-October = $51.47 \mathrm{~mm}$. Egg wet $\mathrm{wt}=\mathrm{egg}$ dry wt (i.e. $15.4 \mu \mathrm{g}$; Tucker $1989 / / 0.2=77.0 \mu \mathrm{g}$.

Growth rate estimates were calculated from seasonal increments of mean weight that were derived from seasonal modal lengths of the different age groups. In addition to the acoustic-calibrated production estimates, 2 alternative estimates were also made, based upon different Initial Estimated Biomasses (IEB) in October and Spawning Biomasses (SB) in June: (1) IEB and $S B$ from uncalibrated trawl survey biomasses; (2) IEB and SB from acoustic-calibrated trawl data, but body weights derived from von Bertalanffy modelpredicted weights and mortality rate from catch-curveestimated annual $Z$ expressed for specific time periods (i.e. 1, 2, or 4 mo, depending on time interval to be estimated). This estimate assumed that bimonthly or 4-monthly instantaneous mortalities subsequent to recruitment were equal for all age groups. Results of the 2 alternative approaches were compared with the original estimate (i.e. acoustic-calibrated IEB and SB, and estimated seasonal $G$ and $Z$ ) to determine possible bounds on levels of production

Population consumption. The expected population consumption by bay anchovy and its seasonal variabil- ity were estimated from information on daily ration and water temperature (Vazquez 1989, Klebasko 1991) applied to the acoustic-calibrated trawl biomass estimates. We also compared our estimates with those of Luo \& Brandt (1993) who used a bioenergetics model to estimate consumption by bay anchovy.

\section{RESULTS}

During the $2 \mathrm{yr}$ study, 1.09 million bay anchovies weighing $647.1 \mathrm{~kg}$ were collected. A total of 357 trawl tows were made.

\section{Seasonal length frequencies}

Seasonal length-frequency distributions were compared based on collections from the Choptank and Point no Point transects in 1990 and 1991 (Fig. 2). In both years, YOY anchovies were recruiting in August before attaining their peak trawl-catch abundances by October. Catches in all months were dominated by YOY anchovies. In October and December 1990, the bimodal length-frequency distributions consisted of 2 groups of YOY anchovy plus older anchovies. The smaller YOY group, which apparently originated from late spawning, was not observed in 1991. Because specific sampling dates differed between years, mean length differences in the monthly distributions (Fig. 2) do not imply growth differences between years without an aging analysis.

\section{Relative abundance and biomass}

In both years, newly recruited bay anchovy became common in August and attained possible peaks in biomass and abundance in October (Fig, 3). The summer abundances (August) of newly recruited anchovies were similar in 1990 and 1991 ( $p>0.05)$. Mean relative abundance of fully recruited anchovies in October 1991 (79.20 per $\left.100 \mathrm{~m}^{3}\right)$ and 1990 (65.21 per $\left.100 \mathrm{~m}^{3}\right)$, and mean relative biomass in October

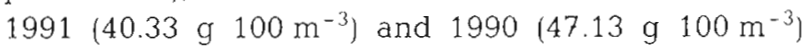
did not differ significantly between years $(p>0.05)$. However, relative abundance and biomass were significantly higher in April 1991 than in April 1990 (p < 0.05 ). The ratios of peak to lowest abundances and biomasses were 52.8 and 55.4, respectively, indicating $>50$-fold variability in seasonal means. A sharp decline in bay anchovy abundance and biomass, probably attributable to both southward migration and mortality, occurred between October and December (Fig. 3). 

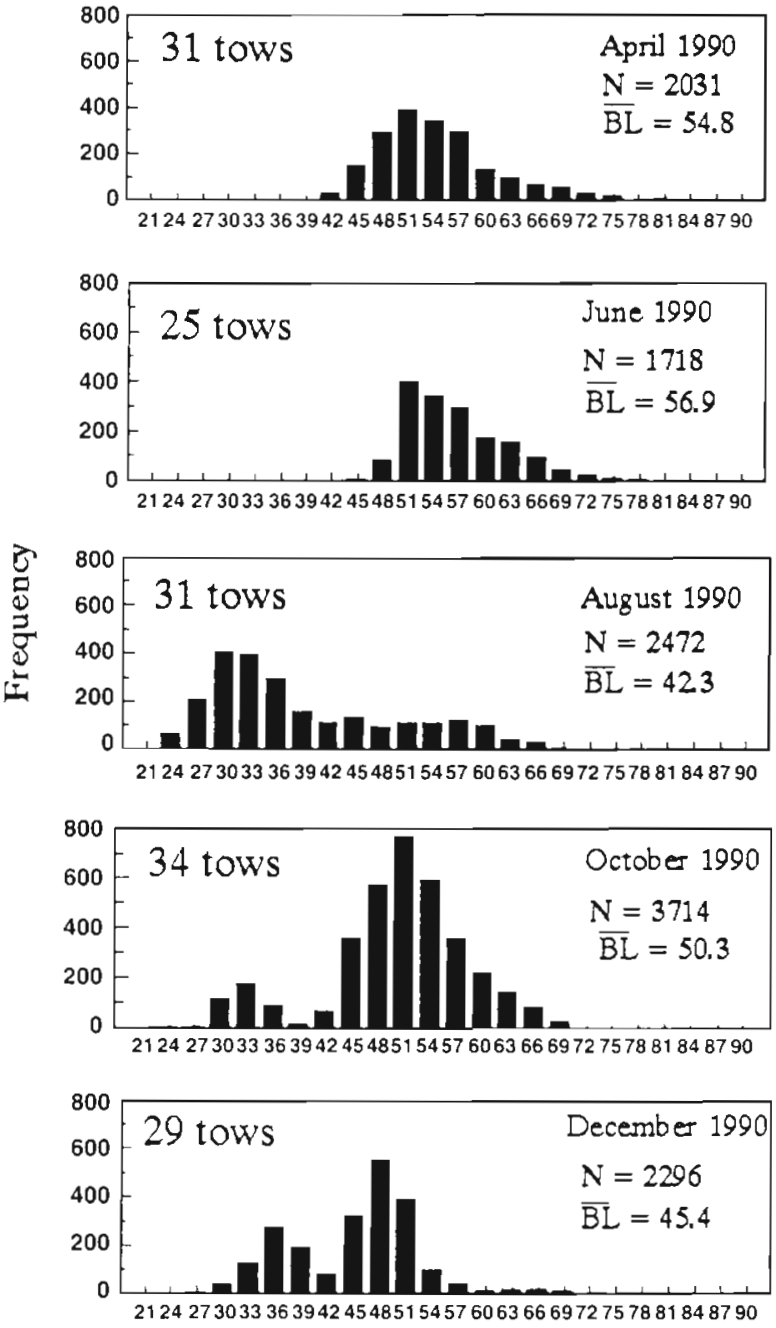

Length midpoint ( $\mathrm{mm}$ )
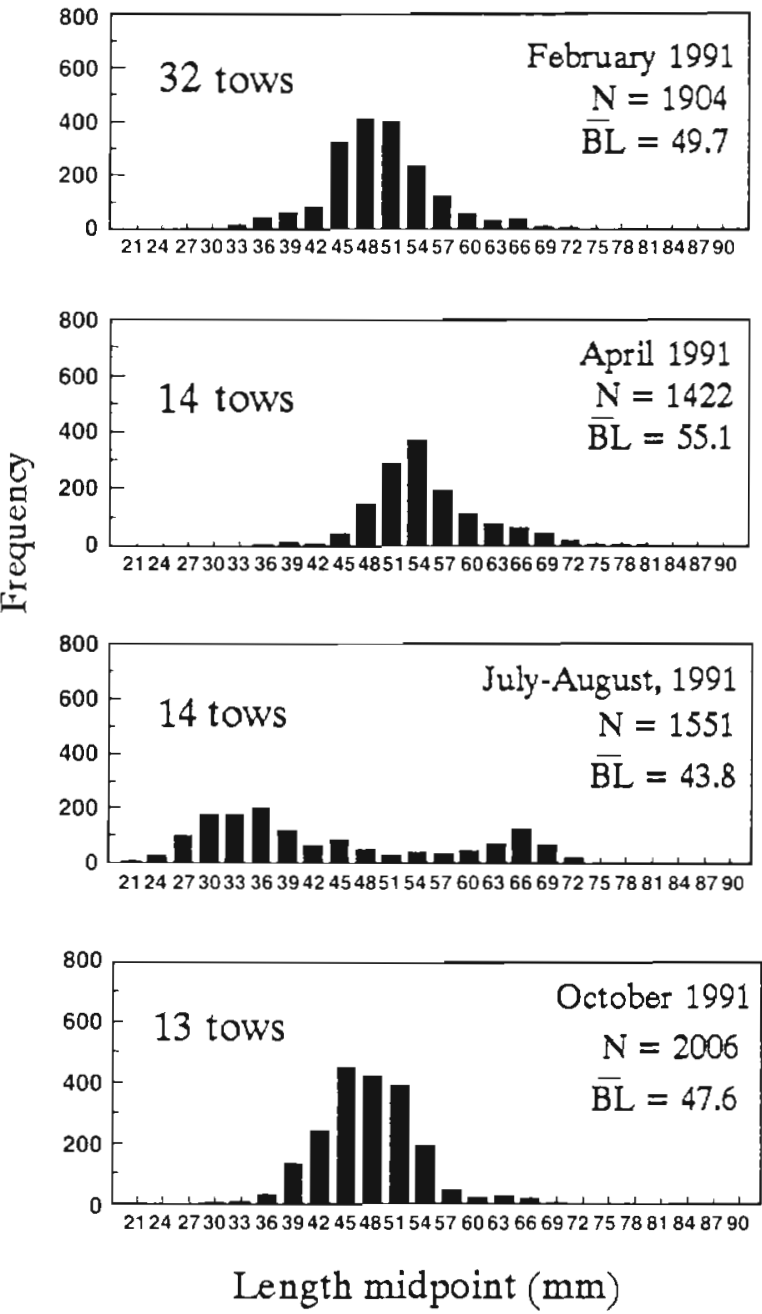

Fig. 2. Anchoa mitchilli. Length-frequency distributions of bay anchovy from samples collected on the Choptank and Point no Point transects in 1990 and 1991. N: number of fish measured, $\overline{B L}$ : mean total body length (mm) of fish that were measured

Relative abundances and biomasses of bay anchovy differed seasonally among transects (Figs, 4 \& 5). In April 1990, anchovies were more abundant at Point no Point than at Choptank ( $p<0.05)$. Abundance and biomass were nearly equal at Point no Point and Choptank in June (Fig. 4). By August 1990, relative abundance and biomass were higher along the upper Bay transect, Still Pond, than at Choptank ( $p<0.05)$. By late October, relative abundance and biomass were highest at Choptank and Point no Point ( $p<0.05$ ) (Fig. 4). In December 1990 , very low catches were obtained on the 3 transects that were sampled, presumably because most anchovies had emigrated from the sampling areas

In February 1991, relative abundances and biomasses began to increase (Fig. 5). By April, bay anchovies were most abundant on the Smith Point to

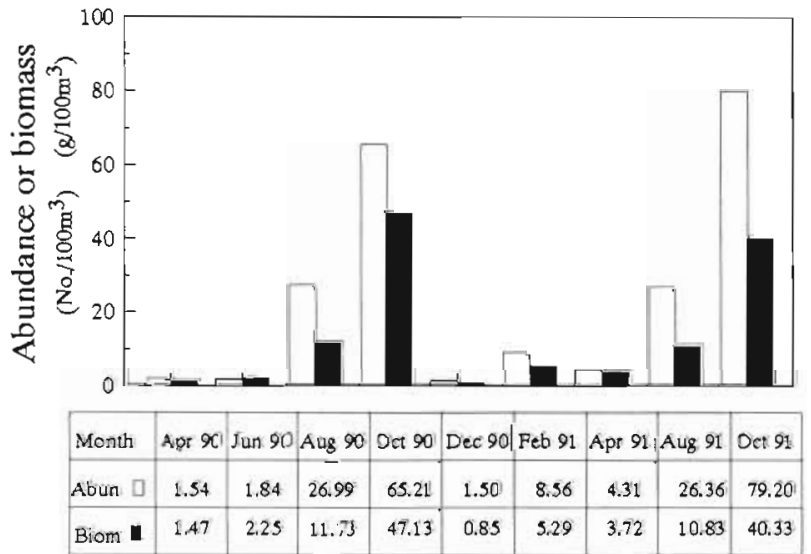

Fig. 3. Anchoa mitchilli. Seasonal trends in relative abundance and biomass of bay anchovy from April 1990 to October 1991 
Table 1. Anchoa mitchilli. Comparisons of trawl survey and acoustic estimates of relative abundance $\left(\right.$ no. $\mathrm{m}^{-3}$ ) of bay anchovy in Chesapeake Bay. Acoustic data were based upon the percentage of fish smaller than $90 \mathrm{~mm}$ (target size) in the water column, which were assumed to be bay anchovy

\begin{tabular}{|lccc|}
\hline Date & Trawl survey (A) & Acoustics (B) & Ratio B:A \\
\hline Apr 20,1990 & 0.023 & 1.328 & 57.74 \\
Jun 9, 1990 & 0.016 & 0.429 & 26.81 \\
Aug 15,1990 & 0.423 & 0.969 & 2.29 \\
Oct 24,1990 & 0.427 & 1.870 & 4.38 \\
Dec 7, 1990 & 0.037 & 0.266 & 7.19 \\
Feb 18,1991 & 0.152 & 2.190 & 14.41 \\
\hline
\end{tabular}

Choptank transects (CT, PT, SM > SP, GB; p < 0.05). During the recruitment season (August 1991), anchovies were widely and quite evenly distributed throughout the sampling area $(p>0.05)$. In October 1991, anchovy biomass was evenly distributed (Fig. 5), but there was a trend of decreasing abundance from the upper toward the mid Bay $\left(\mathrm{GB}>\mathrm{PT}, \mathrm{SM}_{i} \mathrm{p}<0.05\right)$.

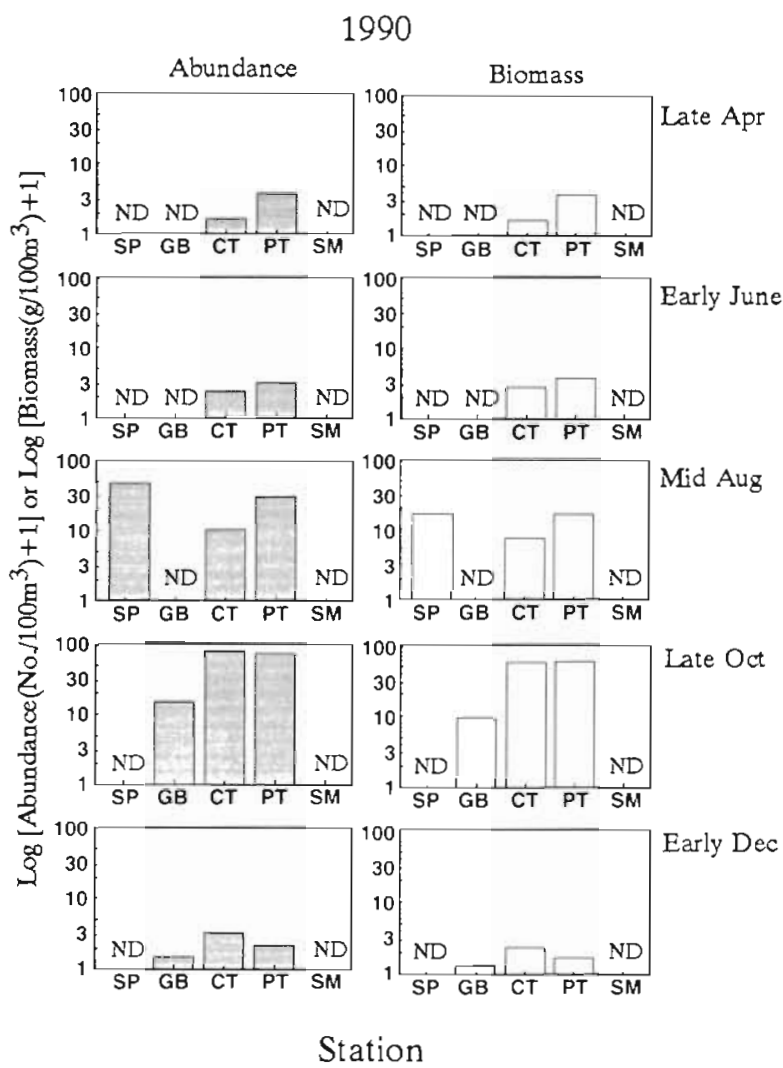

Fig. 4. Anchoa mitchilli. Seasonal variations in mean relative abundance and biomass of bay anchovy among transects in 1990. SP: Still Pond; GB: Greenberry Point; CT: Choptank; PT. Point no Point; SM: Smith Point; ND: no data. Transect locations shown in Fig. 1 Abundance $=$ no. $100 \mathrm{~m}^{-3}$; biomass $=$ g $100 \mathrm{~m}^{-3}$ Data are plotted on a logarithmic scale
Comparison of relative abundances from trawl collections with acoustic-derived estimates for the same dates and times on the Point no Point transect gave acoustics:trawl ratios between 2.3 and 57.7 (Table 1). Ratios were lowest during August and October when anchovies were small and abundant, and highest in April and June, when anchovies were larger but least abundant.

\section{Biomass, nitrogen biomass, production and energy storage}

The estimated initial population biomass (i.e. eggs) during the peak spawning season (July) was $47.24 \mathrm{~g}$ $100 \mathrm{~m}^{-3}$, which equals an egg production of 613503.3 eggs $100 \mathrm{~m}^{-3}$. The YOY cumulative mortality $Z$ from mid-July to mid-October $=-7.84$, and the mortality from mid-July to mid-August $=-5.74$. By difference, $Z=-2.10$ for the mid-August to mid-October period. The uncalibrated back-calculated abundance of bay anchovy in August was then estimated to be 448.06 ind. $100 \mathrm{~m}^{-3}$ for age $0+$ fish, and 13.14 ind. $100 \mathrm{~m}^{-3}$ for age $1+\mathrm{fish}$. Estimated uncalibrated rela-

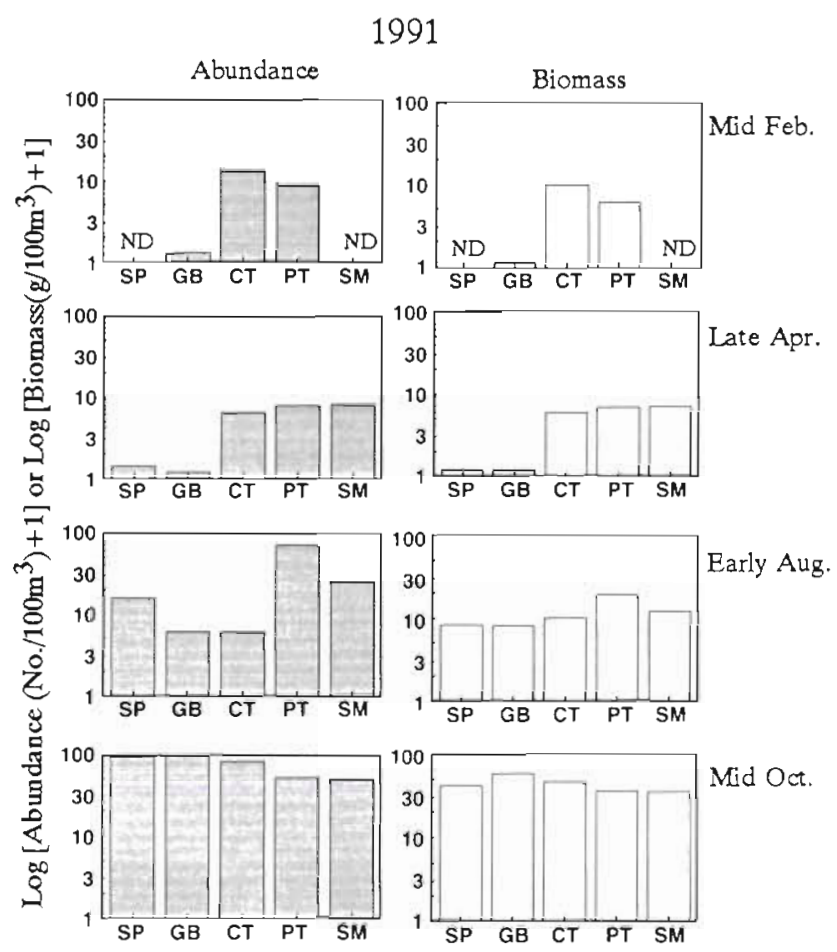

Station

Fig. 5. Anchoa mitchilli. Seasonal variations in mean relative abundance and biomass of bay anchovy among transects in 1991. Abbreviations as in Fig. 4. Transect locations shown in Fig. 1. Abundance $=$ no. $100 \mathrm{~m}^{-3}$; biomass $=g 100 \mathrm{~m}^{-3}$ Data are plotted on a logarithmic scale 
Table 2. Anchoa mitchilli. Seasonal weight-specific growth $(G)$ and cumulative mortality $(Z)$ rates of bay anchovy, and estimated biomass $\left(B, \mathrm{~g} 100 \mathrm{~m}^{-3}\right)$, mean biomass $\left(\bar{B}, \mathrm{~g} 100 \mathrm{~m}^{-3}\right.$ period $\left.{ }^{-1}\right)$, production $\left(P, \mathrm{~g} 100 \mathrm{~m}^{-3}\right.$ period $\left.{ }^{-1}\right)$, ash-free energy storage ( $\left.E, \mathrm{cal} \mathrm{m}^{-3}\right)$, nitrogen biomass $\left(\mathrm{NB}, \mathrm{g} \mathrm{N} 100 \mathrm{~m}^{-3}\right)$ and nitrogen production $\left(N P, \mathrm{~g} \mathrm{~N} 100 \mathrm{~m}^{-3}\right.$ period-1)

\begin{tabular}{|c|c|c|c|c|c|c|c|c|c|}
\hline Date & Age & $a$ & $Z$ & $B$ & $\bar{B}$ & $P$ & $E$ & $N B$ & $N P$ \\
\hline Jul & $\begin{array}{l}\text { Egg } \\
\text { Age 1+ }\end{array}$ & & & $\begin{array}{l}47.24 \\
58.31\end{array}$ & & 47.24 & $\begin{array}{l}594.87 \\
707.30\end{array}$ & $\begin{array}{l}1.41 \\
1.48\end{array}$ & 1.41 \\
\hline $\begin{array}{l}\text { (Jul-Aug) } \\
\text { (Jun-Aug) }\end{array}$ & $\begin{array}{l}\text { YOY } \\
\text { Age } 1+\end{array}$ & $\begin{array}{l}6.29 \\
0.18\end{array}$ & $\begin{array}{l}5.74 \\
0.15\end{array}$ & & $\begin{array}{l}62.88 \\
59.14\end{array}$ & $\begin{array}{r}395.62 \\
10.59\end{array}$ & & & $\begin{array}{l}8.94 \\
0.25\end{array}$ \\
\hline Aug & $\begin{array}{l}\text { YOY } \\
\text { Age 1+ }\end{array}$ & & & $\begin{array}{l}81.63 \\
81.40\end{array}$ & & & $\begin{array}{l}673.46 \\
884.04\end{array}$ & $\begin{array}{l}1.84 \\
1.91\end{array}$ & \\
\hline (Aug-Oct) & $\begin{array}{l}\text { YOY } \\
\text { Age 1+ }\end{array}$ & $\begin{array}{r}2.88 \\
-0.06\end{array}$ & $\begin{array}{l}2.10 \\
0.30\end{array}$ & & $\begin{array}{r}123.96 \\
68.18\end{array}$ & $\begin{array}{r}357.50 \\
-4.37\end{array}$ & & & $\begin{array}{r}9.88 \\
-0.10\end{array}$ \\
\hline Oct & $\begin{array}{l}\text { YOY } \\
\text { Age 1+ }\end{array}$ & & & $\begin{array}{r}178.88 \\
56.46\end{array}$ & & & $\begin{array}{r}1896.69 \\
590.94\end{array}$ & $\begin{array}{l}4.94 \\
1.33\end{array}$ & \\
\hline (Oct-Feb) & $\begin{array}{l}\text { YOY } \\
\text { Age 1+ }\end{array}$ & $\begin{array}{l}0.29 \\
0.14\end{array}$ & $\begin{array}{l}0.73 \\
0.60\end{array}$ & & $\begin{array}{r}144.62 \\
45.14\end{array}$ & $\begin{array}{r}41.74 \\
6.20\end{array}$ & & & $\begin{array}{l}0.94 \\
0.13\end{array}$ \\
\hline Feb & $\begin{array}{l}\text { YOY } \\
\text { Age 1+ }\end{array}$ & & & $\begin{array}{r}115.05 \\
35.44\end{array}$ & & & $\begin{array}{r}1064.52 \\
325.21\end{array}$ & $\begin{array}{l}2.60 \\
0.77\end{array}$ & \\
\hline (Feb-Apr) & $\begin{array}{l}\text { YOY } \\
\text { Age 1+ }\end{array}$ & $\begin{array}{l}0.26 \\
0.14\end{array}$ & $\begin{array}{l}0.77 \\
0.30\end{array}$ & & $\begin{array}{l}90.22 \\
32.75\end{array}$ & $\begin{array}{r}23.67 \\
4.62\end{array}$ & & & $\begin{array}{l}0.56 \\
0.11\end{array}$ \\
\hline Apr & $\begin{array}{l}\text { YOY } \\
\text { Age 1+ }\end{array}$ & & & $\begin{array}{l}69.25 \\
30.21\end{array}$ & & & $\begin{array}{l}808.39 \\
375.79\end{array}$ & $\begin{array}{l}1.65 \\
0.72\end{array}$ & \\
\hline (Apr-Jun) & $\begin{array}{l}\text { YOY } \\
\text { Age 1+ }\end{array}$ & $\begin{array}{l}0.37 \\
0.13\end{array}$ & $\begin{array}{l}0.39 \\
0.30\end{array}$ & & $\begin{array}{l}68.60 \\
27.81\end{array}$ & $\begin{array}{r}25.56 \\
3.70\end{array}$ & & & $\begin{array}{l}0.56 \\
0.09\end{array}$ \\
\hline Jun & $\begin{array}{l}\text { New age } 1+ \\
\text { New age } 2+\end{array}$ & & & $\begin{array}{l}67.93 \\
25.54\end{array}$ & & & $\begin{array}{l}823.99 \\
309.80\end{array}$ & $\begin{array}{l}1.71 \\
0.65\end{array}$ & \\
\hline $\begin{array}{l}\text { (Jun-Jul) } \\
\text { Jul }\end{array}$ & $\begin{array}{l}\text { (New age } 1+\text { ) } \\
\text { New age } 1+\end{array}$ & 0.19 & 0.20 & 67.27 & 67.60 & 12.60 & 599.90 & 1.65 & 0.31 \\
\hline \multicolumn{6}{|c|}{$\begin{array}{l}\text { Total annual production (age } 0+\text { and age } 1+\text { ) } \\
\text { Overall annual } P / \bar{B} \text { ratio for YOY }\end{array}$} & $\begin{array}{r}924.66 \\
8.07\end{array}$ & & & 23.08 \\
\hline
\end{tabular}

tive biomass was $18.64 \mathrm{~g} 100 \mathrm{~m}^{-3}$ for age $0+[=448.06$ ind. $100 \mathrm{~m}^{-3} \times 0.0416 \mathrm{~g}$ (mean weight for $19.27 \mathrm{~mm}$

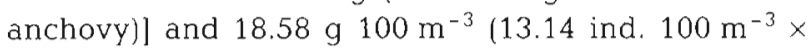
$1.414 \mathrm{~g}$ ) for age $1+$ fish in August. After calibrating abundance data, using the acoustic/trawl ratio in October (4.38) (Table 1), the adjusted biomass in midAugust was $81.63 \mathrm{~g} 100 \mathrm{~m}^{-3}$ for age $0+$ and $=81.4 \mathrm{~g}$ $100 \mathrm{~m}^{-3}$ for age $1+$ fish (Table 2 ).

The cumulative growth rate from hatching to 1 mo old in July-August was 6.29 (from $\bar{W}_{\text {mid-Aug }}=\bar{W}_{\text {mid-Jul }} \mathrm{e}^{G i}$, where $t=1, \bar{W}_{\text {mid-Aug }}=0.0416 \mathrm{~g}$ for a $19.27 \mathrm{~mm}$ fish and $\bar{W}_{\text {mud-Jul }}=$ mean egg weight). The mean biomass present between mid-July and mid-August $=62.88 \mathrm{~g}$ $100 \mathrm{~m}^{-3}$ (Table 2). Production of larvae and early juveniles, from the egg stage to 1 mo posthatch, $=G \times \bar{B}=$ $395.62{\mathrm{~g} 100 \mathrm{~m}^{-3}}^{-3}$

The estimated production of YOY bay anchovy was highest during its earliest life stage, attaining $753.12 \mathrm{~g}$ $100 \mathrm{~m}^{-3}$ during the first 3 mo after hatching (Table 2). Biomass of YOY reached its maximum (178.88 $\mathrm{g}$
$100 \mathrm{~m}^{-3}$ ) in October. Production from the peak spawning date to the period of full recruitment (mid-October) accounted for $87.9 \%$ of the YOY annual production, of which $46.2 \%$ was larval production, produced from spawning to early juvenile (15 July to 15 August) and $41.7 \%$ was produced during the subsequent juvenile recruitment period (mid-August to mid-October). The annual production by age 1+ anchovy, including eggs, is a small fraction of the total (only about $7.4 \%$ of total production) (Table 2).

Estimated stage-specific energy storage, nitrogen biomass and nitrogen biomass production of bay anchovy in the upper and mid Chesapeake Bay also peaked during the early life stages (Table 2) and was lowest just before the spawning season (July). The total annual nitrogen production by bay anchovy in the upper and mid Bay was $23.08 \mathrm{~g} \mathrm{~N} 100 \mathrm{~m}^{-3}$. Ash-free energy stored in the bay anchovy population was highest during October when peak biomass was reached and lowest just before the spawning 
Table 3. Anchoa mitchilli. Estimates of ash-free energy (kcal $100 \mathrm{~m}^{-3}$ ) stored in the bay anchovy population at different locations in Chesapeake Bay during 1991. Data are based upon acoustic-calibrated trawl abundances; SP, GB, PT and SM are sampling transects in the Bay (Fig. 1). Data in parentheses are estimated from trawl surveys before acousticcalibration adjustment

\begin{tabular}{|cccccc|}
\hline \multirow{2}{*}{ Month } & \multicolumn{5}{c}{ Location } \\
& SP & GB & CT & PT & SM \\
\hline \multirow{2}{*}{ Apr } & 8.17 & 8.77 & 206.68 & 244.28 & 258.44 \\
& $(0.23)$ & $(0.24)$ & $(5.71)$ & $(6.72)$ & $(7.11)$ \\
Aug & - & 94.36 & 120.40 & 233.12 & 129.58 \\
& & $(6.27)$ & $(8.00)$ & $(15.49)$ & $(8.61)$ \\
Oct & 265.02 & 348.19 & 312.33 & 230.43 & 203.88 \\
& $(38.97)$ & $(51.21)$ & $(45.93)$ & $(33.88)$ & $(29.98)$ \\
\hline
\end{tabular}

season. In addition, energy stored in the bay anchovy population was highest on our southernmost transects during April 1991 (Table 3) before the spawning season. However, when new recruits began to enter the population in August, and by October when anchovy were fully recruited, energy was distributed relatively evenly throughout the upper and mid Bay.

The overall annual production to mean biomass ratio $(P / \bar{B})$ for YOY fish was 0.97 without accounting for production of larvae and juveniles during the first 3 mo posthatch, but was 8.07 when those stages were included (Table 2 ). The seasonal production to mean biomass ratio $(P / \bar{B})$, which is equivalent to stagespecific $G$ (Table 2), was 6.29 for YOY anchovies from mid-July to mid-August, but was only 0.19 for new age $1+$ anchovy immediately before the peak spawning season. Production of YOY anchovy from October to February was reduced significantly due to low growth rate in winter (bimonthly $G=0.14$ ) and apparent emigration from the sampling areas.

Production estimates under different assumptions were compared in Table 4. The unadjusted trawl data yielded the lowest annual YOY production estimate of

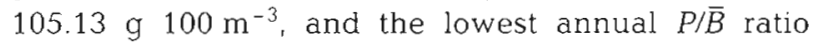
(4.82). The acoustic-calibrated data produced a maximum YOY production estimate of $856.69{\mathrm{~g} 100 \mathrm{~m}^{-3}}^{-3}$ annual production and the highest $P / \bar{B}$ ratio $(8.07)$. The results predicted using the von Bertalanffy model, based on annual $Z=-1.81$ (Wang 1992), yielded an estimate of $816.65 \mathrm{~g} 100 \mathrm{~m}^{-3}$ in annual YOY production and a $P / \bar{B}$ ratio of 6.17 . The estimates derived from the acoustic-calibrated October biomass data (Table 4 , columns $B$ and $C$ ), which are believed to be the best estimates of production, gave similar results in total production despite the differences in stage-specific seasonal production. The differences among the production estimates had 2 causes - the initial estimated biomass in October and the spawning biomass estimated in June.

The total annual production of bay anchovy in the upper and mid Chesapeake Bay regions was obtained by multiplying the estimated production value ii.e.

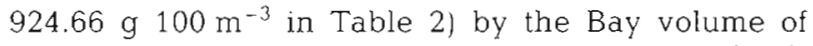
upper and mid Chesapeake Bay $\left(=2.52 \times 10^{10} \mathrm{~m}^{3}\right)$ (Cronin 1971). Total annual production was estimated to be $233014 \mathrm{t}$, which was derived almost entirely $(92.6 \%)$ from YOY fish. The production by age $1+$ fish was minor (only $7.4 \%$ ).

\section{Population consumption}

Population consumption was estimated, based upon daily ration information from (A) Vazquez (1989) and (B) Klebasko (1991) (Table 5). The population con-

Table 4. Anchoa mitchilli. Comparison of mean biomass and production estimates for YOY bay anchovy based upon different assumptions and sources of data (IEB: Intial Estimated Biomass in October; SB: Spawning Biomass in June; see text for details). (A) Minimum estimate: using estimated bimonthly $G$ and $Z_{i}$ and IEB and SB from unadjusted trawl-survey data. (B) Maximum estimate: using estimated bimonthly $G$ and $Z$; both IEB and SB from acoustic-calibrated trawl data. (C) Using von Bertalanffy model-predicted body weight and catch-curve estimated $Z$ (Wang 1992); IEB and SB from acoustic-calibrated trawl data

\begin{tabular}{|c|c|c|c|c|c|c|}
\hline \multirow[t]{2}{*}{ Date } & \multicolumn{3}{|c|}{$\begin{array}{c}\text { Mean biomass } \\
\left.\text { (g } 100 \mathrm{~m}^{-3} \text { period }^{-1}\right)\end{array}$} & \multicolumn{3}{|c|}{$\begin{array}{c}\text { Production } \\
\left({\mathrm{g} 100 \mathrm{~m}^{-3} \text { period }}^{-1}\right)\end{array}$} \\
\hline & (A) & (B) & (C) & (A) & (B) & (C) \\
\hline Jul-Aug 1990 & 4.42 & 62.88 & 79.25 & 27.83 & 395.62 & 673.71 \\
\hline Aug-Oct 1990 & 18.60 & 123.96 & 118.74 & 53.65 & 357.50 & 26.99 \\
\hline Oct 1990-Feb 1991 & 33.02 & 144.62 & 161.63 & 9.53 & 41.74 & 64.16 \\
\hline Feb-Apr 1991 & 20.60 & 90.22 & 1.36 .68 & 5.40 & 23.67 & 23.90 \\
\hline Apr-Jun 1991 & 15.66 & 68.60 & 119.63 & 5.84 & 25.56 & 19.36 \\
\hline Jun-Jul 1991 & 15.43 & 67.60 & 111.52 & 2.88 & 12.60 & 8.53 \\
\hline Total YOY production: & & & & 105.13 & 856.69 & 816.65 \\
\hline
\end{tabular}


Table 5. Anchoa mitchilli. Acoustic-calibrated anchovy biomass ( $\mathrm{g}$ wet wt $100 \mathrm{~m}^{-3}$ ), daily ration (\% of dry body weight) and estimated population consumption ( $g$ dry wt zooplankton $100 \mathrm{~m}^{-3} \mathrm{~d}^{-1}$ ) by the bay anchovy population in upper and mid Chesapeake Bay. Dry/wet ratio assumed equal to 0.2. (A) Based upon Vazquez's (1989) estimated daily rations. Fish size: 40 to 76 mm. (B) Based on Klebasko's (1991) estimated daily rations, where: 'based on fish $>48 \mathrm{~mm}$; ' based on fish $<48 \mathrm{~mm}$. Biomasses in April, August and October were the mean values of the 2 years' data. Biomass in June and December were estimated from the 1990 collections

\begin{tabular}{|lccccc|}
\hline Month & $\begin{array}{c}\text { Calibrated anchovy } \\
\text { biomass }\end{array}$ & $\begin{array}{c}\text { Daily ration } \\
\text { (A) }\end{array}$ & $\begin{array}{c}\text { Population } \\
\text { consumption (A) }\end{array}$ & $\begin{array}{c}\text { Daily ration } \\
\text { (B) }\end{array}$ & $\begin{array}{c}\text { Population } \\
\text { consumption (B) }\end{array}$ \\
\hline Apr & 94.28 & - & - & $2.3 \cdot$ & 0.43 \\
Jun & 48.85 & 13.1 & 1.28 & $3.0^{*}$ & 0.68 \\
Aug & 163.03 & 16.2 & 5.29 & $1.4^{*}$ & 12.81 \\
Oct & 297.36 & 9.0 & 5.35 & $1.1^{*}$ & 6.78 \\
Dec & 5.68 & - & - & 0.01 \\
\hline
\end{tabular}

sumption was highest during August: (A) 5.29 or (B) $12.81 \mathrm{~g}$ dry wt $100 \mathrm{~m}^{-3} \mathrm{~d}^{-1}$ corresponding to the period of highest water temperatures and high biomass of YOY anchovy. Consumption was also high in October: (A) 5.35 or (B) $6.78 \mathrm{~g}$ dry wt $100 \mathrm{~m}^{-3} \mathrm{~d}^{-1}$. In other months, population consumptions were relatively small. The estimated absolute population consumptions (monthly) by bay anchovy in the upper and mid Bay were (A) 41325 or (B) $100072 \mathrm{t}$ in August and (A) 41794 or (B) $52965 \mathrm{t}$ in October based upon daily rations (Vazquez 1989, Klebasko 1991) and the upper to mid-Bay water volume (Cronin 1971).

\section{DISCUSSION}

\section{Biomass and production}

If bay anchovy have a significant impact on the Chesapeake Bay ecosystem, it potentially will be in the summer to fall seasons when their abundance and biomass peak. Overall abundances and biomasses were similar in 1990 and 1991, but there were significant seasonal changes in relative abundance and biomass. At least 50 -fold differences in abundance of the recruited length-classes were observed between seasons.

Peak biomass (in October) was reached after the period of maximum production during the larval and youngest juvenile stages (between July and October). The early-life production of larvae and juveniles, from hatching (July) to mid-October, accounted for $87.9 \%$ of the annual YOY production. Highest production and biomass periods in summer and fall corresponded to the seasons when large piscivores also are most abundant in Chesapeake Bay (Baird \& Ulanowicz 1989), suggesting that the fluctuations of bay anchovy biomass and production may be important with respect to availability of food for these fishes (Hartman 1993).
To explore how errors in estimating mean length or weight of anchovy during the recruitment period could affect production, we repeated our analysis with mean lengths smaller and larger than those believed to be our best estimate. If the mean length at capture in August (34.8 mm) accurately represented modal size in August, rather than the $19.27 \mathrm{~mm}$ length in our analysis (Table 2), then the total annual production of

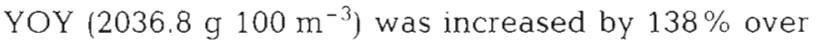

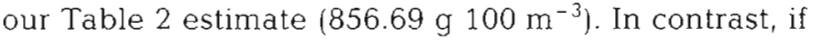
mean length had been $<19.27 \mathrm{~mm}$, for example $15 \mathrm{~mm}$ (i.e. mean growth rate $=0.5 \mathrm{~mm} \mathrm{~d}^{-1}$ from hatch to $1 \mathrm{mo}$

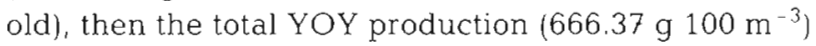
was $22.2 \%$ below the Table 2 estimate. Errors in estimating mean modal length of bay anchovy in trawl collections in August will have significant effects on population production estimates. Arrhenius \& Hansson (1993) also reported a dramatic effect of choosing alternative lengths or growth rates of larval-stage herring Clupea harengus and sprat Sprattus sprattus (L.) in their estimates of stage-specific food consumption by these fishes. We believe that our estimate, which was based on back-calculated mean length (i.e. $19.27 \mathrm{~mm}$ ) from mean length at capture in October and mean growth rate of otolith-aged anchovy collected on midChesapeake Bay (Zastrow et al. 1991), accurately reflected the modal mean length of YOY in August, and thus provided a reliable production estimate.

The $P / \bar{B}$ ratio is an index of productive potential that is species-specific, but also sensitive and dependent upon the life stages that are included in its calculation (Chapman 1978). Typical values of $P / \bar{B}$ for freshwater invertebrates range from 2.5 to 5 , with a mean of 3.5 . Values for fishes (Sissenwine 1987, Waters et al. 1990) generally are lower. The $P / \bar{B}$ of bay anchovy in Chesapeake Bay is much higher than reported values for most other species of fish. Bay anchovy annual $P / \bar{B}=$ 8.07 , when earliest-life stages were included, but was only 0.97 without the larval and youngest juvenile stages. Seasonal $P / \bar{B}$ was highest in August (6.29), indi- 
cating that the highest productive potential of bay anchovy is in the larval and smallest juvenile stages.

The bay anchovy is essentially an annual fish with high growth and mortality rates. Its seasonal $P$ and $P / \bar{B}$ ratio indicated that most of its annual production occurs in the first 3 mo posthatch. Production of the youngest age groups of fishes sometimes may exceed that of all other age groups combined (Chapman 1978). For example, Mathews (1970) reported that production of age $0+$ fish constituted most of the fish production in the Thames River. Allen (1951) and Hunt (1966) found that $95 \%$ of brown trout and 80 to $95 \%$ of brook trout production, respectively, occurred during first $2 \mathrm{yr}$ of life. For species like bay anchovy, it is essential that early life stages be included in the production estimates. Otherwise, production will be very much underestimated and may not accurately represent the stage-specific or overall trophic status of a species.

Our estimated population production of bay anchovy in the upper to mid-Chesapeake Bay was $233014 \mathrm{t}$, which was mostly attributed to larval and juvenile stages. Luo \& Brandt (1993) developed a bioenergetics model from which they estimated population production of bay anchovy in mid-Chesapeake Bay to be $30771 \mathrm{~kg} \mathrm{~km}^{-2}$, which translates to $119297 \mathrm{t}$ in the upper to mid Bay (based on mean depth $=6.5 \mathrm{~m}$ and water volume $=2.52 \times 10^{10} \mathrm{~m}^{3}$; Cronin 1971). The Luo \& Brandt (1993) result, which is about half of our estimate, was based upon bay anchovy growth and mortality rates in 1987 (Newberger \& Houde 1995) and, most importantly, did not include the highly productive youngest stages (anchovies $<40 \mathrm{~d}$ old).

\section{Seasonal migration}

It is possible that the larger sizes of anchovies began to migrate from the sampling areas to the lower Bay in October. A bimodal length-frequency distribution had been observed in October and December 1990. However, after accounting for potential growth, most fish in the larger modal group (with peak at 50 to $51 \mathrm{~mm}$ and greater) in October were nearly absent in December catches and thereafter (February and April 1991) Possible explanations for the disappearance of the larger modal length group were (1) migration from the sampling area to the lower Bay or out of the Bay and (2) size-selective mortality by predation. It is conceivable that major losses of the larger length-group of anchovy could have been caused by size-selective predation during the fall. But, it seems unlikely that the dramatic reduction in abundance was attributable solely to predation because the larger anchovies had accounted for $>65 \%$ of the population in October.
When monthly trawl catches of bay anchovy in Virginia waters (lower Bay areas) (Bonzek et al. 1989. 1990,1991 ) were compared with those from our study, it was found that between August and December, when peak abundances occurred in our mid-Bay areas, catches were smallest in the lower Bay. In December, this pattern was reversed. Mean lengths of bay anchovy in October increased from the upper Bay toward the mid Bay in 1991 (Wang 1992). And, anchovies in the lower Bay areas were even larger when compared with mid-Bay catches (mean length $=52.7 \mathrm{~mm}$ in lower Bay during October 1990 and 1991; Bonzek et al. 1990, 1991). These observations strongly suggest a southward migration of the larger anchovies in the fall.

The population levels of bay anchovy in Barnegat Bay, New Jersey, USA, are believed to be regulated largely by overwinter survival and return migration patterns of the overwintering population from the inner continental shelf (Vouglitois et al. 1987). Luo \& Musick (1991) found that in lower Chesapeake Bay, bay anchovy abundance in winter was positively correlated with water temperature, suggesting that emigration out of the Bay may be more pronounced in cold winters.

In our study, relative abundance and biomass of bay anchovy in April 1991 were significantly higher than in April 1990. This result corresponded to the warmer winter in 1991 and colder winter in 1990. Catches-perunit-effort in annual trawl surveys in the lower Bay were significantly lower in January 1990 (0.2 tow ${ }^{-1}$ ) than in January 1991 (1160.5 tow ${ }^{-1}$ ) (Bonzek et al. $1990,1991)$. This evidence indicates that overwinter survival, as well as southward migration, play important roles in determining spring-season abundance and spawning biomass of bay anchovy in the midChesapeake Bay.

\section{Energy and mass translocation}

If much of the bay anchovy biomass migrates to the lower Chesapeake Bay, there is a large biomass and energy flow from the upper and middle Bay to lower Bay regions during late fall to winter Thus, the energy storage in the anchovy population is dynamic and changes seasonally. Because bay anchovy is an important forage species in the Bay, its seasonal migration pattern and variation could have significant impact on the Bay ecosystem

Emigration and loss of biomass have been reported in another forage species, Atlantic silversides Menidia menidia (Conover \& Murawski 1982, Conover \& Ross 1982), in which the winter migration of silversides represented a one-way export of biomass from shallow marsh to deeper, offshore waters. Similarly, transloca- 
tion of nutrients and energy from estuaries to coastal marine ecosystems via Gulf menhaden Brevoortia patronus migration has been reported (Deegan 1993). About 5 to $10 \%$ of annual primary production in estuaries of the Gulf of Mexico was exported via menhaden migration.

In bay anchovy, an estimated $1027 \mathrm{t}$ of nitrogen biomass may have been translocated to the lower Bay via migration. This value is $-0.8 \%$ of the estimated 130900 t of annual nitrogen input to Chesapeake Bay (Correll 1987). Because our research did not extend to lower Bay areas, it was not possible to evaluate how much nitrogen might be exported from the Bay as bay anchovy. However, from indirect evidence on emigration (Luo 1991), we speculate that emigration and translocation of nitrogen may be more significant during cold winters than in warm winters.

\section{Population consumption}

Our estimates of zooplankton consumption by bay anchovy were highest in August when temperatures were high and the population was dominated by fastgrowing larval and early juvenile anchovies. Recent bioenergetics modeling (Luo \& Brandt 1993) applied to the juvenile and adult bay anchovy, based upon high daily consumption rate estimates (i.e. $60 \%$ of body weight in contrast to 16.2 to $27.6 \%$ body weight in our study), indicated maximum consumption in September (3.353 $\mathrm{g}$ wet wt $\mathrm{m}^{-2} \mathrm{~d}^{-1}$ ). This model result is within the range of our August estimates (converted to wet wt $\left.\mathrm{m}^{-2} \mathrm{~d}^{-1}\right), 1.72$ to $4.16 \mathrm{~g}$ wet wt $\mathrm{m}^{-2} \mathrm{~d}^{-1}$, but was higher than our October estimate $\left(1.74\right.$ to $2.20 \mathrm{~g}_{\text {wet }}$ wt $\mathrm{m}^{-2}$ $\mathrm{d}^{-1}$ ). It seems probable that the highest stage-specific consumption by bay anchovy occurs during late summer before recruitment is completed, and is a consequence of high seasonal temperature and high growth demand.

Our high consumption estimate by anchovy at an early life stage is not unique among fishes. Similar results were also observed in other fast-growing clupeids (Hewett \& Stewart 1989, Arrhenius \& Hansson 1993) and may be generally true for abundant, short-lived fishes. In a study of food consumption by larval, young and adult herring and sprat in the Baltic Sea, Arrhenius \& Hansson (1993) demonstrated that peak consumption occurred during the summer, when larvae and YOY accounted for 50 and $45 \%$, respectively, of the total consumption of zooplankton. The authors concluded that previous research which had yield estimates 4 times lower were a consequence of not including larvae and YOY stages. Hewett \& Stewart (1989) also reported that about $10 \%$ of total annual zooplankton consumption by Lake Michigan alewives could be attributed to larval fish feeding during their first $40 \mathrm{~d}$ of life. YOY and larval fish together could have accounted for $50 \%$ of total annual consumption. And, predation by the alewife population had a strongly seasonal pattern in which $45 \%$ of total annual consumption occurred in August and September, with $73 \%$ occurring in the July through October period. The evidence indicates that early life stages of many fishes cannot be ignored if seasonal or annual population consumption and production are to be estimated. Our results demonstrated the high seasonal consumption levels by the bay anchovy population in Chesapeake Bay, indicating that its top-down impact and its potential importance as a regulator of piscivore production may be substantial, at least during summer and fall when bay anchovy is at peak biomass and abundance.

Acknowledgements. Research was supported by NOAA, Department of Commerce, Maryland Sea Grant R/F-65, NSF Grants OCE8701304 and OCE9203307, Sport Fishing Institute via the Electric Power Research Institute (EPRI), and the Potomac Electric Power Company (PEPCO). We thank Drs J. H. Cowan Jr and J. Luo for their critical reviews and valuable comments.

\section{LITERATURE CITED}

Allen KR (1951) The Horokiwi Stream: a study of a trout population. Fish Bull NZ 10:1-238

Arrhenius F, Hansson S (1993) Food consumption of herring and sprat in the Baltic Sea. Mar Ecol Prog Ser 96: $125-137$

Baird D, Ulanowicz RE (1989) The seasonal dynamics of the Chesapeake Bay ecosystem. Ecol Monogr 59:329-364

Bigelow HB, Schroeder WC (1953) Fishes of the Gulf of Maine. US Fish Wildl Serv Fish Bull 74:1-577

Bonzek CF, Geer PJ, Colvocoresses JA, Harris RE (1989) Juvenile finfish and blue crab stock assessment. Bottom trawl survey. Annual Report Series No 124, Vol 1989. Virginia Institute of Marine Science, Gloucester Point

Bonzek CF, Geer PJ, Colvocoresses JA, Harris RE (1990) Juvenile finfish and blue crab stock assessment. Bottom trawl survey. Annual Report Series No 124, Vol 1990. Virginia Institute of Marine Science, Gloucester Point

Bonzek CF, Geer PJ, Colvocoresses JA, Harris RE (1991) Juvenile finfish and blue crab stock assessment. Bottom trawl survey. Annual Report Series No 124, Vol 1991. Virginia Institute of Marine Science, Gloucester Point

Chapman DW (1978) Production in fish populations. In: Gerking $S B$ (ed) Ecology of freshwater fish production. John Wiley and Sons, New York, p 5-25

Chesapeake Executive Council (1988a) Living resources monitoring plan. Chesapeake Bay Program, Annapolis, MD

Chesapeake Executive Council (1988b) Stock assessment plan. Chesapeake Bay Program, Annapolis, MD

Conover DO, Murawski SA (1982) Offshore winter migration of the Atlantic silverside, Menidia menidia. Fish Bull US 80:145-149

Conover DO, Ross MR (1982) Patterns in seasonal abundance, growth and biomass of the Atlantic silverside, Menidia menidia, in a New England estuary. Estuaries 5(4):275-286 
Correll DL (1987) Nutrients in Chesapeake Bay. In: Majumdar SK, Hall LW, Austin HM (eds) Contaminant problems and management of living Chesapeake Bay resources. The Pennsylvania Academy of Science Publications, Easton, p 298-320

Cronin WB (1971) Volumetric, areal and tidal statistics of the Chesapeake Bay, estuary and its tributaries. Chesapeake Bay Institute, The John Hopkins University, Baltimore, Special Report 20

Deegan LA (1993) Nutrient and energy transport between estuaries and coastal marine ecosystems by fish migration. Can J Fish Aquat Sci 50:74-79

DeMelo R, France R, McQueen DJ (1992) Biomanipulation: hit or myth? Limnol Oceanogr 37(1):192-207

Dorsey SE (1993) Daily variability in mortality of bay anchovy (Anchoa mitchilli) eggs and yolk-sac larvae in Chesapeake Bay, USA Master's thesis, The University of Maryland, College Park

Dowgiallo A (1975) Chemical composition of an animal's body and of its food. In: Gradzinski W, Klekowski RZ, Duncan A (eds) Methods for ecological bioenergetics. IBP handbook no 24. Blackwell Scientific Publications, London, p 160-184

Hartman K (1993) Striped bass, bluefish, and weakfish in the Chesapeake Bay: energetics, trophic linkage, and bioenergetics model applications. PhD dissertation, The University of Maryland, College Park

Hewett SW, Stewart DJ (1989) Zooplanktivory by alewives in Lake Michigan: ontogenetic, seasonal, and historical patterns. Trans Am Fish Soc 118:581-596

Hildebrand SF, Schroeder WC (1928) Fishes of Chesapeake Bay. Fish Bull US 43:1-388

Horwitz RJ (1987) Fish. In: Heck KL Jr (ed) Ecological studies in the middle reach of Chesapeake Bay. Lecture notes on coastal and estuarine studies 23. Springer Verlag, Berlin, p $167-224$

Houde ED (1988) Variability of factors that affect recruitment of bay anchovy. The University of Maryland, Chesapeake Biological Laboratory. Progress Report to NSF. Ref No [UMCEES]CBL 89-039

Houde ED, Zastrow CE (1991) Bay anchovy. In: Funderburk SL, Mihursky JA, Jordan SJ, Riley D (eds) Habitat requirements for Chesa peake Bay living resources, 2nd edn. Living Resources Subcommittee, Chesapeake Bay Program, Annapolis, p 1-14

Hunt BP (1966) Production and angler harvest of wild brook trout in Lawrence Creek, Wisconsin. Tech Bull Wis Conserv Dept 35

Johnson WS, Allen DM, Ogburn MV, Stancyk SE (1990) Short-term predation responses of adult bay anchovy Anchoa mitchilli to estuarine zooplankton availability Mar Ecol Prog Ser 64:55-68

Kitchell JF, Carpenter SR (1987) Piscivores, planktivores, fossils, and phorbins. In: Kerfoot WC, Sih A (eds) Predation: direct and indirect impacts on aquatic communities. University Press of New England, Hanover, p $132-146$

Klebasko MJ (1991) Feeding ecology and daily ration of bay anchovy, Anchoa mitchilli in the mid-Chesapeake Bay. Master's thesis, The University of Maryland, College Park

Luo J (1991) Life history of the bay anchovy, Anchoa mitchilli, in Chesapeake Bay. PhD dissertation, School of Marine Science, College of William \& Mary, Williamsburg, VA

Luo J, Brandt SB (1993) Bay anchovy production and

This article was presented by K. L. Heck Jr (Senior Editorial Advisor), Dauphin Island, Alabama, USA consumption in mid-Chesapeake Bay based on a bioenergetic model and acoustic measures of fish abundance. Mar Ecol Prog Ser 98:223-236

Luo J, Musick JA (1991) Reproductive biology of the bay anchovy, Anchoa mitchilli, in Chesapeake Bay. Trans Am Fish Soc 120:701-710

Mathews CP (1970) Estimates of production with reference to general surveys. Oikos 21:129-133

McQueen DJ, Johannes MRS, Post JR (1989) Bottom-up and top-down impacts on freshwater pelagic community structure. Ecol Monogr 59(3):289-309

McQueen DJ, Post JR, Mills EL (1986) Trophic relationships in freshwater pelagic ecosystems. Can J Fish Aquat Sci 43:1571-1581

Merriner IV (1975) Food habits of the weakfish, Cynoscion regalis, in North Carolina waters. Chesapeake Sci $16: 74-76$

Newberger TA, Houde ED (1995) Population biology of bay anchovy in the mid-Chesapeake Bay. Mar Ecol Prog Ser 116:25-37

Newman RM, Martin RB (1983) Estimation of fish production rates and associated variances. Can J Fish Aquat Sci 40:1729-1736

Ricker WE (1975) Computation and interpretation of biological statistics of fish populations. Bull Fish Res Bd Can 191

SAS (1985) SAS user's guide, 1985 edn. SAS Institute, Cary, $\mathrm{NC}$

Sissenwine MP (1987) Fish and squid production. In: Backus RH, Bourne DW (eds) Georges Bank. The MIT Press, Cambridge

Summers JK (1989) Simulating the indirect effects of power plant entrainment losses on an estuarine ecosystem. Ecol Model 49:31-47

Tucker JW Jr (1989) Energy utilization in bay anchovy. Anchoa mitchilli, and black sea bass, Centropristis striata, eggs and larvae. Fish Bull US 78:279-293

Vazquez AV (1989) Energetics, trophic relationships and chemical composition of bay anchovy. Anchoa mitchilli, in the Chesapeake Bay. Master's thesis, University of Maryland, College Park

Vouglitois JJ, Able KW, Kurtz RJ, Tighe KA (1987) Life history and population dynamics of the bay anchovy in New Jersey. Trans Am Fish Soc 116:141-153

Wang SB (1992) Abundance, relative biomass, production and energy storage of bay anchovy, Anchoa mitchilli, in the Chesapeake Bay. MS thesis, The University of Maryland, College Park

Wang SB, Houde ED (1994) Energy storage and dynamics in bay anchovy, Anchoa mitchilli. Mar Biol 121:219-227

Waters TF (1977) Secondary production in inland waters. Adv ecol Res 10:91-164

Waters TF, Doherty MT, Krueger CC (1990) Annual production and production:biomass ratios for three species of stream trout in Lake Superior tributaries. Trans Am Fish Soc 119:470-474

Wilk SJ (1977) Biological and fisheries data on bluefish, Pomatomus saltatrix (Linnaeus). Nat Mar Fish Serv, NE Fish Centre, Sandy Hook, NJ, Tech Ser Rep 11

Zastrow CE, Houde ED, Morin LG (1991) Spawning, fecundity, hatch-date frequency and young-of-the-year growth of bay anchovy Anchoa mitchilli in mid Chesapeake Bay. Mar Ecol Prog Ser 73:161-171

Manuscript first received: April 4, 1994

Revised version accepted: December 17, 1994 